\title{
Sub-daily variability of suspended sediment fluxes in small mountainous catchments - implications for community-based river monitoring
}

\author{
C. Duvert ${ }^{1}$, N. Gratiot ${ }^{1}$, J. Némery ${ }^{2}$, A. Burgos ${ }^{3}$, and O. Navratil ${ }^{4}$ \\ ${ }^{1}$ Laboratoire d'étude des Transferts en Hydrologie et Environnement, UMR 5564, IRD/Université de Grenoble/CNRS, \\ Grenoble, France \\ ${ }^{2}$ Laboratoire d'étude des Transferts en Hydrologie et Environnement, UMR 5564, G-INP, Grenoble, France \\ ${ }^{3}$ Centro de Investigaciones en Geografía Ambiental (CIGA), Universidad Nacional Autónoma de México, Morelia, Mexico \\ ${ }^{4}$ Cemagref, Unité de recherche Érosion Torrentielle, Neige et Avalanches (ETNA), Grenoble, France
}

Received: 11 October 2010 - Published in Hydrol. Earth Syst. Sci. Discuss.: 19 October 2010

Revised: 17 February 2011 - Accepted: 27 February 2011 - Published: 2 March 2011

\begin{abstract}
Accurate estimates of suspended sediment yields depend on effective monitoring strategies. In mountainous environments undergoing intense seasonal precipitation, the implementation of such monitoring programs relies primarily on a rigorous study of the temporal variability of fine sediment transport. This investigation focuses on seasonal and short-term variability in suspended sediment flux in a subhumid region of the Mexican Volcanic Belt. Intensive monitoring was conducted during one year in four contrasting catchments ( 3 to $630 \mathrm{~km}^{2}$ ). Analyses revealed significant temporal variability in suspended sediment export over various time scales, with between 63 and $97 \%$ of the annual load exported in as little as $2 \%$ of the time. Statistical techniques were used to evaluate the sampling frequency required to get reliable estimates of annual sediment yield at the four sites. A bi-daily sampling scheme would be required at the outlet of the $630 \mathrm{~km}^{2}$ catchment, whereas in the three smaller catchments $\left(3-12 \mathrm{~km}^{2}\right)$, accurate estimates would inevitably require hourly monitoring. At the larger catchment scale, analysis of the sub-daily variability of fine sediment fluxes showed that the frequency of sampling could be lowered by up to $100 \%$ (i.e. from bi-daily to daily) if a specific and regular sampling time in the day was considered. In contrast, conducting a similar sampling strategy at the three smaller catchments could lead to serious misinterpretation (i.e. up to $1000 \%$ error). Our findings emphasise the importance of
\end{abstract}

Correspondence to: C. Duvert (clement.duvert@gmail.com) an analysis of the sub-daily variability of sediment fluxes in mountainous catchments. Characterising this variability may offer useful insights for improving the effectiveness of community-based monitoring strategies in rural areas of developing countries. In regions where historical records based on discrete sampling are available, it may also help assessing the quality of past flux estimates. Finally, the study confirms the global necessity of acquiring more high frequency data in small mountainous catchments, especially in poorly gauged areas.

\section{Introduction}

Mountainous subcatchments are known to produce high amounts of fine sediment, because of their steep and incised morphology (Dietrich and Dunne, 1978; Walling and Webb, 1996; Sidle et al., 2000). It is therefore essential to provide accurate sediment flux estimates within these areas, in order to quantify soil loss and eventually to implement appropriate land conservation practices.

De Boer et al. (2003) recently affirmed that " [... ] in many parts of the world, erosion rates and sediment yields are not, or only poorly, monitored. This problem is particularly evident in developing countries, where this information is most urgently required [...]". To offset the data scarcity affecting developing countries, a number of prediction methods have been applied to ungauged basins (e.g. Morehead et al., 2003). However, such techniques are not satisfying in smaller catchments characterized by highly-scattered and unpredictable

Published by Copernicus Publications on behalf of the European Geosciences Union. 
relations between suspended sediment concentration (SSC) and discharge $(Q)$ (Horowitz, 2008). In these situations, direct measurements are the only manner to estimate annual exports of fine sediment (Walling et al., 2003).

In Mexico, the effort has historically been focused on lakes and larger basins, and still very few mountainous catchments are instrumented, despite erosion and water quality problems (Alcocer and Bernal-Brooks, 2010). Natural resources in the rural areas of the country are commonly managed by organised local communities (Velázquez et al., 2003; Bocco et al., 2005). The interest of local stakeholders and citizens in water-related issues is undeniable, as recently outlined by Ortiz-Ávila (2009) in the Michoacán state. This inquiry showed that water contamination and drinking water were among the main environmental priorities of local communities. A few planning initiatives for water quality monitoring are currently being developed in the country (Aranda et al., 2008; Paré et al., 2008), but nationwide, water resource issues are still under-appreciated in the management plans of rural settlements. In the United States and Canada, collaborative and community-based approaches to managing water resources have become increasingly more prevalent in the last decade (e.g. Whitelaw et al., 2003; Deutsch and Orprecio, 2005; Sharpe and Conrad, 2006; Fernandez-Gimenez et al., 2008). Such approaches could be usefully implemented in Mexico, given that the involvement of local volunteers in river monitoring could allow gathering of data in ungauged catchments in a cost-efficient way. Suspended sediment yield (SSY) measurements should systematically be included in these participatory surveys. SSY data are indeed of local interest in rural areas for the identification of a range of incatchment processes, i.e. soil loss rates from cultivated land, useful life of reservoirs, monitoring of sediment-associated contaminants, etc.

A lot of work has been done worldwide on SSY estimates and seasonal and daily variability in sediment export for mesoscale and larger river basins (e.g. Ongley et al., 1977; Walling and Webb, 1981; Milliman and Syvitski, 1992; Meybeck et al., 2003). Errors and bias in SSY estimates associated with sampling frequency have also been extensively characterised for $10^{3}$ to $10^{6} \mathrm{~km}^{2}$ basins (de Vries and Klavers, 1994; Phillips et al., 1999; Horowitz, 2003; Coynel et al., 2004; Moatar et al., 2006). However, very few studies have addressed the question of sub-daily variability within smaller catchments (Mano et al., 2009). Meybeck et al. (2003) only pointed out that SSC variability within catchments under $10 \mathrm{~km}^{2}$ had to be established at fine timescales such as a few hours. But the consequences of an inadequate sampling design, including the choice of an inappropriate sampling time during the day, have, to date, been rarely debated by the scientific community (Mano et al., 2009; Moatar et al., 2009). A better characterisation of the sub-daily variability of sediment fluxes in mountainous catchments is therefore required to improve the efficiency of present-day river monitoring. Additionally, in areas where
SSC has been routinely sampled for a number of decades, quantifying short term variability in suspended sediment flux can be useful for assessing the consistency of these extended time series. Overall, there is a crucial need to promote management strategies based on a close interaction between local groups, management agencies and the scientific institutions (Savan et al., 2003).

Near-continuous monitoring of streamflow and suspended sediment fluxes was conducted in contrasting mountainous catchments $\left(3-630 \mathrm{~km}^{2}\right)$ of the Mexican Highlands. In this paper we aim to provide answers to the following questions: (1) how significant is the seasonal variability in streamflow and suspended sediment, and are there sub-daily fluctuations in the sediment transport regime of the studied streams? (2) Is the effect of sampling frequency quantifiable, and is it site- or catchment size-dependent? (3) Can we deduce relevant community-based monitoring strategies for such mountainous catchments?

\section{Methods}

\subsection{Study site}

The Cointzio basin is located in the southern part of the Mexican Central Plateau, within the Transverse Volcanic Belt (Fig. 1). The region undergoes a temperate subhumid climate characterised by two contrasting seasons: the dry season from November to May and the wet season between June and October. Mean annual rainfall reaches $770 \mathrm{~mm}$ in Morelia. Nearly $80 \%$ of the precipitation occurs during the five months of the rainy season (Carlón-Allende et al., 2009). Rainfall is characterised by a high sub-daily variability, with localised convective storms generally promoting intense precipitation over a few $\mathrm{km}^{2}$ in the late afternoon through early night.

The Cointzio basin drains an area of $630 \mathrm{~km}^{2}$ with altitudes from $3440 \mathrm{~m}$ at the highest point to $1990 \mathrm{~m}$ at the outlet. The main watercourse is the Rio Grande de Morelia river, which reaches the man-made reservoir of Cointzio $\left(4 \mathrm{~km}^{2}, 65 \mathrm{Mm}^{3}\right)$ at the outlet of the catchment. The geology mainly consists of basalt and andesitic rocks. Soils are finely textured; Andisols are prominent in upland parts of the basin, Acrisols on the hillslopes and Luvisols in the lowlands (FAO, 2006).

Sediment concentrations were measured at the outlet of the Cointzio catchment (Undameo station; $630 \mathrm{~km}^{2}$ ) and at three subcatchments. The three upland areas are characterised by contrasting landforms, morphologies and soil types. The subcatchment of La Cortina $\left(9 \mathrm{~km}^{2}\right)$ is underlain by Andisols, and has an undulating landscape (mean slope $12 \%$ ) mainly covered by forests. The Huertitas subcatchment $\left(3 \mathrm{~km}^{2}\right.$; mean slope $\left.18 \%\right)$ relies exclusively on Acrisols mostly covered by rangeland, and it displays a severely gullied landscape with sparse vegetation on $6 \%$ 


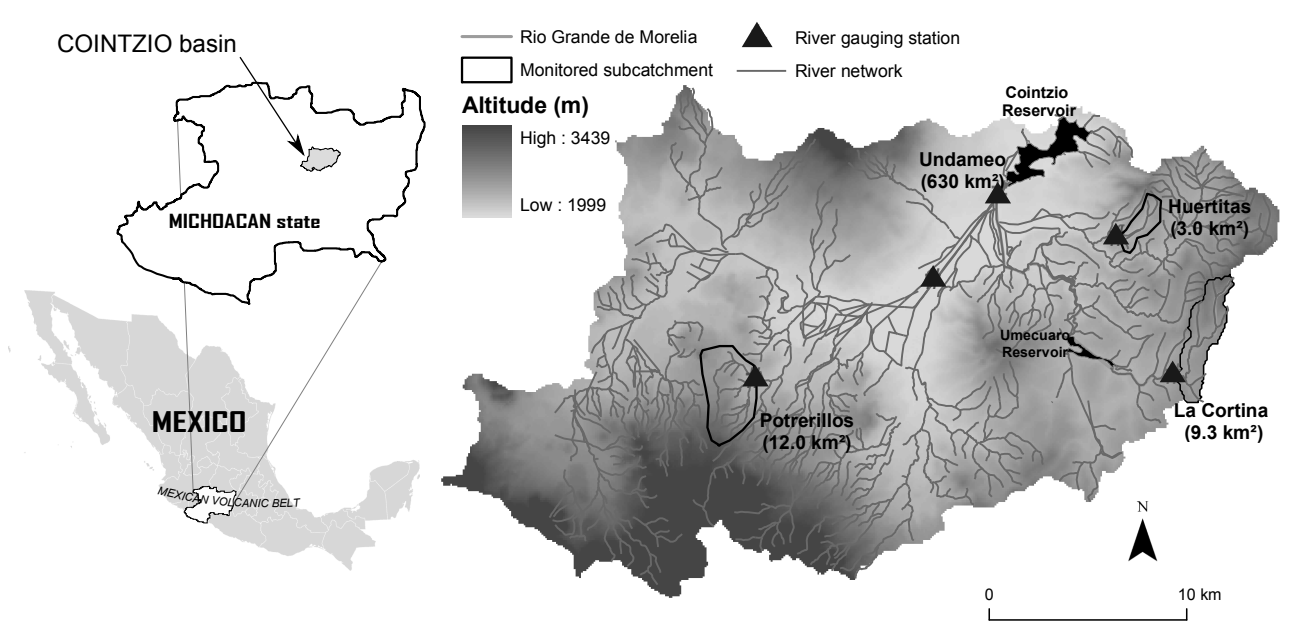

Fig. 1. Location of the Cointzio basin and its four monitored stations (Huertitas, Potrerillos, La Cortina and Undameo).

of its area. Finally, the rolling subcatchment of Potrerillos $\left(12 \mathrm{~km}^{2}\right.$; mean slope $\left.15 \%\right)$ consists of Acrisols and Andisols covered by cropland and rangeland; incised channels and gullies affect $1 \%$ of the subcatchment area (more details can be found in Duvert et al., 2010). High frequency water discharge data were acquired from January 2008 to January 2010 in Undameo and in Potrerillos, and from January 2009 to January 2010 in the two other subcatchments, i.e. La Cortina and Huertitas. Suspended sediment measurements were made from January 2009 to January 2010 at all stations. Suspended sediment fluxes could therefore be estimated throughout 2009 at the four sites.

\subsection{Field sampling and flux estimates}

\subsubsection{At the outlet}

Monitoring at the gauging station of Undameo started in 1939 by the Comisión Nacional del Agua (CONAGUA). At that time a Parshall flume was built to provide a control of the hydraulic section. A stage-discharge rating curve was also established and regularly adjusted. Daily measurements of both water level and SSC were manually conducted by the CONAGUA from 1939 to 2002. For this research, water level was measured at a 5-min time-step with a Thalimede OTT water level gauge. Water discharge time series were then determined via the CONAGUA rating curve.

Turbidity was automatically measured every $10 \mathrm{~min}$ with a WTW Visolid 700-IQ nephelometric sensor using infrared backscattering. Various authors (e.g. Gippel, 1995; Lewis, 1996) showed that continuous time-series of SSC can be efficiently derived from continuous turbidity series if the calibration is frequently adjusted. Indeed, a number of parameters govern the disparities between SSC and turbidity, such as variation in sediment size or colour. 314 samples were collected all throughout 2009, covering both storms and base- flow conditions. This manual sampling was conducted by local families on a daily basis at approx. 07:00 p.m. Calibration of the turbidimeter proved to remain steady during the entire period. We therefore used the same relationship between SSC and turbidity $\left(R^{2}=0.84\right)$ throughout the year for the calculation of SSC series (Némery et al., 2010).

Annual SSY ref $\left(\mathrm{Mg} \mathrm{y}^{-1}\right)$ was obtained from the continuous time series and was used as reference value in this study. It was calculated using the following formula:

$\mathrm{SSY}_{\mathrm{ref}}=\int_{i=1}^{n} \mathrm{SSF} d t$ with $\mathrm{SSF}=\mathrm{SSC} \cdot Q \cdot 10^{-3}$

where SSF is the instantaneous suspended sediment flux $\left(\mathrm{Mg} \mathrm{s}^{-1}\right)$, SSC is the instantaneous suspended sediment concentration $\left(\mathrm{g}^{-1}\right)$ (10-min frequency interpolated to 5-min), $Q$ is the instantaneous discharge $\left(\mathrm{m}^{3} \mathrm{~s}^{-1}\right)$ (5-min frequency), and $n$ is the number of 5-min intervals included in a year. It should be noted that SSY estimates cumulate uncertainties on both SSC and discharge measurements (Lewis and Eads, 2008; Navratil et al., 2011).

\subsubsection{At the three subcatchments}

Water level was surveyed at a 5-min time-step with the same water level gauge as at the catchment's outlet. For each station, a rating curve was developed using stage readings and discharge measurements generated from $\mathrm{NaCl}$ tracer dilution gauging measurements. Discharge time series were determined from continuous water level records and the rating curve. Suspended sediment concentration time series were calculated using stage-triggered Teledyne ISCO 3700 automatic water samplers containing 24 bottles of 1 litre each. Sampling regime during most of the stormflow events reached a 5-min frequency. Further details about the methodology can be found in Duvert et al. (2010). 
Collected samples were filtered in the laboratory of CIGAUNAM in Morelia. The preweighed filters (pore diameter, $0.7 \mu \mathrm{m}$ ) were dried for $2 \mathrm{~h}$ at $105^{\circ} \mathrm{C}$ and weighed again with a high precision balance. In case of very high SSC (about $>1.5 \mathrm{~g} \mathrm{l}^{-1}$ ), a known volume of sample was dried for $24 \mathrm{~h}$ at $60^{\circ} \mathrm{C}$ and the residue was weighed. In this paper, all SSC measurements refer to total suspended sediment (i.e. comprising mineral and organic fractions).

In the three subcatchments, annual SSY ref were calculated following Eq. (1) by using a 5-min interpolation of SSC data obtained from the monitoring. We assumed that suspended sediment flux measured at the three subcatchments through automatic sampling could be assimilated to a high frequency survey. A large majority of the storms was indeed sampled continuously throughout the season (i.e. 5-min frequency), and the less-sampled baseflow fluxes did not represent a significant part of overall fluxes. Based on regular manual sampling conducted during recession phases, baseflow contributed $18 \mathrm{Mg} \mathrm{km}^{-2}$ out of $900 \mathrm{Mg} \mathrm{km}^{-2}$ (i.e. $2 \%$ of total flux) in Huertitas, $4 \mathrm{Mg} \mathrm{km}^{-2}$ out of $600 \mathrm{Mg} \mathrm{km}^{-2}$ (i.e. under $1 \%$ of total flux) in Potrerillos, and $1 \mathrm{Mg} \mathrm{km}^{-2}$ out of $30 \mathrm{Mg} \mathrm{km}^{-2}$ (i.e. $3 \%$ of total flux) in La Cortina.

Various metrics were also calculated at each station to assess the seasonal dynamics of suspended sediment transport. $\mathrm{Ms}_{2} \%$ corresponds to the percentage of annual SSY discharged in $2 \%$ of time (i.e. approx. 7 days); $\mathrm{Ts}_{50 \%}$ refers to the percentage of time needed to carry $50 \%$ of the annual SSY (Meybeck et al., 2003).

\subsection{Sub-sampling simulations}

Following the methodology previously reported by Phillips et al. (1999), Coynel et al. (2004), Moatar et al. (2006), and Mano (2008), we intended to assess the effect of infrequent sampling on the accuracy of annual yield estimates. Various sampling frequencies were therefore simulated by extracting instantaneous SSC values and their corresponding discharges from the high frequency data. Simulations were conducted using the following sampling designs: monthly (S1), fortnightly (S2), weekly (S3), every 3 days (S4), daily (S5), every $12 \mathrm{~h}$ (S6), every $6 \mathrm{~h}$ (S7), every $3 \mathrm{~h}$ (S8) and hourly (S9) frequencies. Subsequent simulated suspended sediment yields were calculated according to "Method 15" described by Phillips et al. (1999):

$\mathrm{SSY}_{\mathrm{sim}}=K \sum_{i=1}^{n s}\left(C_{i} \cdot Q_{i}\right)$

where $C_{i}$ and $Q_{i}$ are respectively the instantaneous SSC and discharge values at the time of sampling, $n s$ is the number of samples taken in a year ( $n s$ ranges between 12 for $\mathrm{S} 1$ and 8760 for S9) and $K$ is a conversion factor depending on the sampling frequency.

For each scenario, all possible simulations were performed, i.e. 8640 combinations for scenario S1, 4320 for S2, 2016 for S3, 864 for S4, 288 for S5, 144 for S6, 72 for S7, 36 for S8, and 12 for S9. Annual SSY obtained from the continuous monitoring were then used as the reference values against which the accuracy of the simulated scenarios was assessed through relative error calculations.

The sub-daily variability of SSY was also analysed. The 288 values recorded each day were therefore separated into 24 groups in order to account for the hour of sampling in the simulations. S5 scenario (i.e. daily sampling frequency) was run 24 times considering every sampling time from 00:00 a.m. to 11:00 p.m. These 24 scenarios are referred to in the text as $\mathrm{S}_{0}, \mathrm{~S}_{1}, \ldots, \mathrm{S}_{22}, \mathrm{~S} 5_{23}$. For each of the $\mathrm{S} 5_{i}$ scenarios, 13 simulations were considered, corresponding to a $1 \mathrm{~h}$ data interval centred on the assessed sampling time. The resulting errors on annual yield estimates were then calculated for every $\mathrm{S}_{i}$ scenario and are discussed in Sect. 3.5.

\section{Results and discussion}

\subsection{Streamflow dynamics}

On average, 29 storm events were recorded at each monitoring station throughout 2009. We therefore hypothesised that these sampled events were statistically representative of the general sediment transport behaviour prevailing in the four studied streams. Furthermore, when compared to long term records available at the outlet of the $630 \mathrm{~km}^{2}$ basin, it appears that 2009 was an average year considering precipitation: total rainfall depth measured in Cointzio during 2009 reached $805 \mathrm{~mm}$, while the historical database presents a mean of $770 \mathrm{~mm} \mathrm{y}^{-1}$ with values in the range $400-1100 \mathrm{~mm} \mathrm{y}^{-1}$ (Gratiot et al., 2010). Mean discharge, however, only reached $1.3 \mathrm{~m}^{3} \mathrm{~s}^{-1}$ in 2009, which was one of the lowest values in more than 60 years. Mean discharge between 1940 and 2002 was $2.2 \mathrm{~m}^{3} \mathrm{~s}^{-1}$.

The primary factor in controlling river flow variability was the meteorological seasonality affecting the region. This pattern is well exemplified in Fig. 2, which shows the discharge records acquired between January 2008 and December 2009 in both Undameo (Fig. 2a) and Potrerillos (Fig. 2b), as well as the discharge records acquired throughout 2009 in both La Cortina (Fig. 2c) and Huertitas (Fig. 2d). The succession of wet and dry periods is visually obvious. This welldefined cycle was observed in all the studied areas. Still, it was more pronounced in the three upland catchments, mainly because of the lower baseflow in upstream areas than in lowland plains during the dry season.

The three subcatchments exhibited very responsive behaviours during floods (Fig. 2b, c, d), with nearly instantaneous rising phases followed by rather short recession limbs (Duvert et al., 2010). Flood durations at the outlet of the $630 \mathrm{~km}^{2}$ catchment (Fig. 2a) were significantly longer (average of $9 \mathrm{~h}$ ) than within upland areas (average of $1 \mathrm{~h}$ in Huertitas to $3 \mathrm{~h}$ in Potrerillos). In 2009, annual specific instantaneous peak discharges ranged as follows: $0.13 \mathrm{~mm} \mathrm{~h}^{-1}$ 


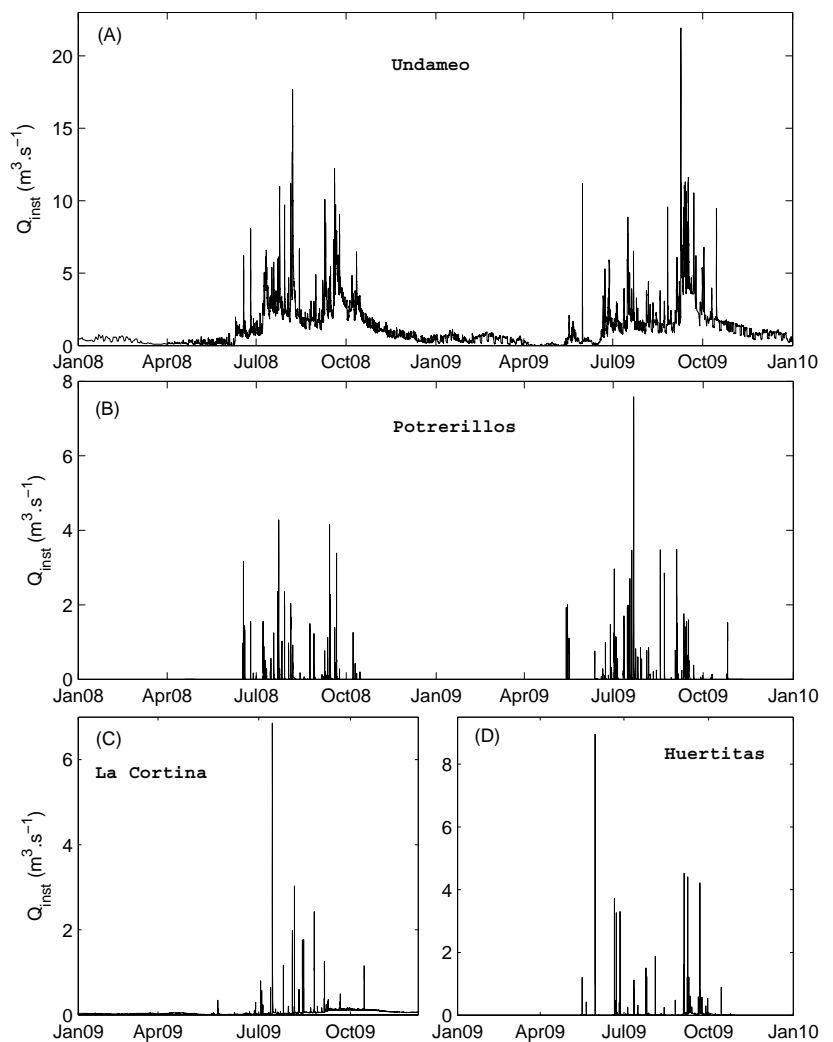

Fig. 2. Discharge records at the four sites. (a and b) correspond to data collected from January 2008 to December 2009 in Undameo and Potrerillos, respectively. (c and d) correspond to data collected from January 2009 to December 2009 in La Cortina and Huertitas, respectively.

in Undameo, $2.5 \mathrm{~mm} \mathrm{~h}^{-1}$ in Potrerillos, $2.9 \mathrm{~mm} \mathrm{~h}^{-1}$ in $\mathrm{La}$ Cortina and $10.8 \mathrm{~mm} \mathrm{~h}^{-1}$ in Huertitas. Annual mean specific discharge $q^{*}$ was also calculated for the four stations, with values ranging from $4 \times 10^{-3} \mathrm{~mm} \mathrm{~h}^{-1}$ in Potrerillos, $7 \times 10^{-3} \mathrm{~mm} \mathrm{~h}^{-1}$ in Undameo, to $22 \times 10^{-3} \mathrm{~mm} \mathrm{~h}^{-1}$ in $\mathrm{La}$ Cortina and $32 \times 10^{-3} \mathrm{~mm} \mathrm{~h}^{-1}$ in Huertitas. These values outline the heterogeneity in the hydrological response of each of the catchments.

Significant discrepancies were evident in the streamflow regimes of the four monitored catchments. Annual instantaneous peak discharge was inversely related to catchment sizes, most likely because smaller areas statistically receive higher amounts of rainfall given the spatial restriction of rainstorms (Milliman and Syvitski, 1992). Overall, the four sites were exposed to a very high seasonal and daily variability in precipitation and streamflow, which proved to be even more accentuated in smaller catchments.

\subsection{Seasonal and daily dynamics of SSY}

Annual SSY reached $900 \mathrm{Mg} \mathrm{km}^{-2}$ in Huertitas (low estimate), $600 \mathrm{Mg} \mathrm{km}^{-2}$ in Potrerillos (low estimate) and
Table 1. Temporal variability of suspended sediment for each station.

\begin{tabular}{lrccr}
\hline & $\begin{array}{r}\text { Area } \\
\left(\mathrm{km}^{2}\right)\end{array}$ & $\begin{array}{c}\mathrm{Ms}_{2 \%} \\
(\%)^{1}\end{array}$ & $\begin{array}{c}\mathrm{Ts}_{50 \%} \\
(\%)^{2}\end{array}$ & $\begin{array}{r}\mathrm{Ts}_{50 \%} \\
\text { (time-equivalent) }\end{array}$ \\
\hline Undameo & 630 & 63 & 1.2 & 4 days $10 \mathrm{~h}$ \\
Potrerillos & 12 & 97 & 0.1 & $11 \mathrm{~h}$ \\
La Cortina & 9 & 93 & $4 \times 10^{-2}$ & $4 \mathrm{~h}$ \\
Huertitas & 3 & 96 & $3 \times 10^{-2}$ & $2 \mathrm{~h}$ \\
\hline
\end{tabular}

${ }^{1} \mathrm{Ms}_{2} \%$ is the percentage of annual SS flux discharged in $2 \%$ of time.

${ }^{2} \mathrm{Ts}_{50 \%}$ is the percentage of time needed to carry $50 \%$ of the annual SS flux.

$30 \mathrm{Mg} \mathrm{km}^{-2}$ in La Cortina (Duvert et al., 2010). At the outlet of the Cointzio catchment (Undameo station), SSY was estimated at $45 \mathrm{Mg} \mathrm{km}^{-2}$. According to the classification proposed by Meybeck et al. (2003), annual SSY were "medium" in Undameo and La Cortina and "very high" in Potrerillos and Huertitas. Catchment characteristics such as land cover, steepness and degree of land degradation were the prevailing factors explaining the differences in SSY (Duvert et al., 2010; Evrard et al., 2010).

Given the strong seasonality observed in the streamflow records, we aimed to check whether the sediment transport regime was characterised by a comparable variability. Some typical metrics were therefore calculated, and the duration curves of annual suspended sediment flux were produced for each site (these curves were obtained by displaying the percent of suspended sediment flux versus the percent of time). According to Fig. 3 and Table 1, half of the annual load ( $\mathrm{Ts}_{50 \%}$ ) was carried in less than $0.1 \%$ to $1.2 \%$ of time, and in 7 days $\left(\mathrm{Ms}_{2} \%\right)$ the rivers exported between 63 and $97 \%$ of annual flux. The highest variability was observed in Huertitas and the lowest in Undameo.

Meybeck et al. (2003) calculated the $\mathrm{Ms}_{2} \%$ of several small basins $\left(64-500 \mathrm{~km}^{2}\right)$ from their global database, and they found values reaching 50 to $90 \%$. Mano et al. (2009) observed $\mathrm{Ms}_{2} \%$ values ranging from 38 to $84 \%$ in four small to medium-sized catchments of the French Alps. Therefore, our results are comparable with those previous studies. According to the $\mathrm{Ts}_{50} \%$ and $\mathrm{Ms}_{2} \%$ indicators, the sediment flux duration patterns ranged from "very short" in Undameo to "extremely short" in Potrerillos, La Cortina and Huertitas (Table 1). This outlines the predominant contribution of a few large events in the annual SSY of these highly responsive basins, as already reported by several authors worldwide (e.g. Syvitski and Morehead, 1999; Meybeck et al., 2003; Mano et al., 2009). Overall, SS flux was very variable and catchment size proved to be the main driver of this variability. Indeed, $\mathrm{Ms}_{2} \%$ mostly decreased and $\mathrm{Ts}_{50 \%}$ increased with increasing catchment size. 


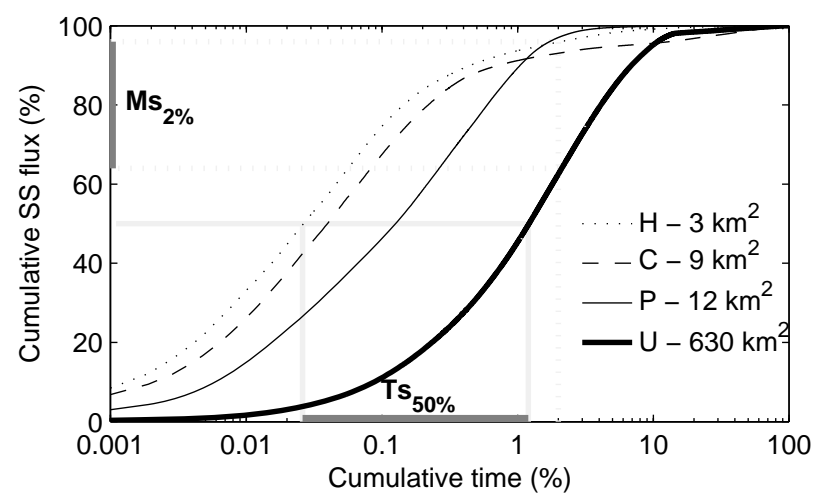

Fig. 3. Suspended sediment flux duration curves at the four stations. Grey lines correspond to the range of the $\mathrm{Ms}_{2} \%$ and $\mathrm{Ts}_{50 \%}$ parameters.

\subsection{Influence of sampling frequency on SSY estimates}

The results obtained from the nine sub-sampling simulations (S1 to S9) are presented in Fig. 4. Figure 4a outlines the maximum errors obtained among all simulations on annual yield estimates for each scenario (vertical axis) and for each catchment (horizontal axis). If we consider that a deviation between simulated and reference yield estimates falling within the $\pm 20 \%$ range is acceptable in terms of reliability (e.g. Navratil et al., 2011), the minimum sampling frequencies would be a bi-daily sampling strategy (i.e. S6 scenario) for Undameo, whereas for the three subcatchments an hourly sampling (i.e. S9 scenario) would be needed (Fig. 4a). Error due to sampling design was much more significant in the three subcatchments than in the whole basin; again, this is evidence of scale effects. For instance, if considering a bi-daily sampling (i.e. S6 scenario), maximum errors on annual yield estimate could reach 17\% in Undameo, 240\% in Potrerillos, $420 \%$ in La Cortina and up to $540 \%$ in Huertitas.

Figure $4 \mathrm{~b}$ shows the relative errors between the upper or lower quartile of each simulation and the reference fluxes (the selected quartile value was the one of the two falling furthest from the median). At every site, the errors on flux estimates decreased significantly with increasing sampling frequencies. Based on the analysis of Fig. 4b, the adapted sampling frequency could be lowered to $3 \mathrm{~h}$ in La Cortina and Potrerillos.

Figure $4 \mathrm{c}$ presents the distribution of errors between the median values of each simulation and the reference fluxes. A systematic negative bias was observed in the median values of S1 to S4 scenarios in Undameo and in the median values of $\mathrm{S} 1$ to $\mathrm{S} 7 \mathrm{scenarios}$ in the three upland catchments. This bias was related to the temporal non-linearity of sediment fluxes, as illustrated in Fig. 3.

Despite corresponding to the most probable scenarios, the information provided in Fig. 4c has to be regarded as an optimistic picture, given that the distribution of errors was not accounted for. To a lesser extent, the minimum sampling frequencies proposed in Fig. 4b also have to be considered as potentially risky, as these values did not account for the largest errors. In contrast, the results shown in Fig. 4a represent "worst case" scenarios, and basing a sampling design on those results can be thought of as a more secure, though more time constraining, approach.

Whatever the error considered (i.e. maximum, quartile or median), the minimum monitoring frequency required to get reliable sediment yield estimates was found to be highly catchment size-dependent (Fig. 4). This can be explained by the high temporal variability of discharge and SSC, because of the shorter and flashier nature of streamflow in the upland subcatchments as compared to the larger Cointzio catchment. A similar pattern has been observed by Horowitz (2008) for catchments of contrasting sizes $\left(1 \times 10^{3}\right.$ to $\left.5 \times 10^{4} \mathrm{~km}^{2}\right)$ in North America. On the whole, reliable SSY estimates in small mountainous catchments appeared to require very high sampling frequencies.

\subsection{Sub-daily variability in SSY}

Given the particular characteristics of rainfall in the region (i.e. precipitation activity generally peaking in late afternoon to early night), the potentially resulting sub-daily variability in SSY was assessed. We therefore analysed the distribution of suspended sediment exports all throughout the day and on an hourly basis. The distribution of events during the day was also determined by counting all peak flow occurrences included in each 1-h time interval. The results are detailed in Fig. 5. In Undameo (Fig. 5a), fluxes were distributed irregularly during the day, with higher loads discharged during the night and lower loads during the day. The peak in export occurred around midnight (ca. 30\% of the total yield exported in $5 \mathrm{~h}$ ). At the three subcatchments (Fig. 5b, $\mathrm{c}, \mathrm{d})$, the temporal variability in sediment export was much more significant. Conditions with high SS fluxes prevailed during the late afternoon. In Potrerillos (Fig. 5b), almost all the SSY (i.e. $>85 \%$ ) occurred between 05:00 p.m. and 03:00 a.m. In La Cortina (Fig. 5c), over 90\% of sediment was exported between 05:00 p.m. and midnight. In Huertitas (Fig. 5d), the bulk of sediment (i.e. $>60 \%$ ) reached the outlet between 03:00 p.m. and 07:00 p.m. The distribution of peak flow events during the day followed the same pattern as sediment loads at all stations; this confirms that the trends described by the daily cycle of total yields are not biased by a few single events.

Overall, sub-daily variability in SSY proved to be very significant. Again, this variability was closely related with catchment size. Our results show that the fluctuations in SSY were much larger in upstream catchments than in the entire basin. We therefore hypothesise that such temporal variability may have critical consequences on the manual sampling strategies to be implemented. 


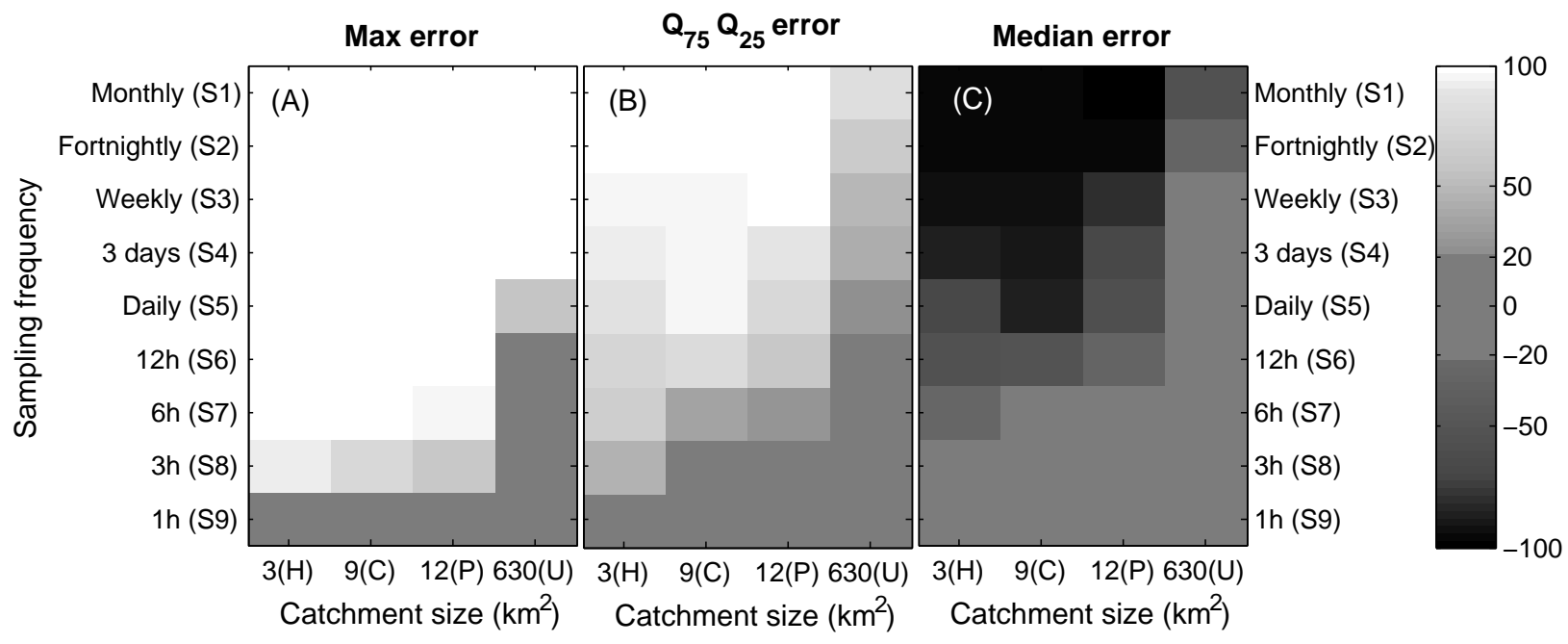

Fig. 4. Influence of the sampling frequency on SSY estimates depending on various strategies (from 1 sample per month, S1, to 1 sample per hour, S9), at each station. The degree of error on SSY estimates was represented by a grey-scale gradation: white cells correspond to a 100\% positive bias whereas black cells correspond to a $100 \%$ negative bias. Marked grey cells represent values belonging to the $\pm 20 \%$ range. (a) Maximum errors. (b) Highest quartile errors. (c) Median errors.
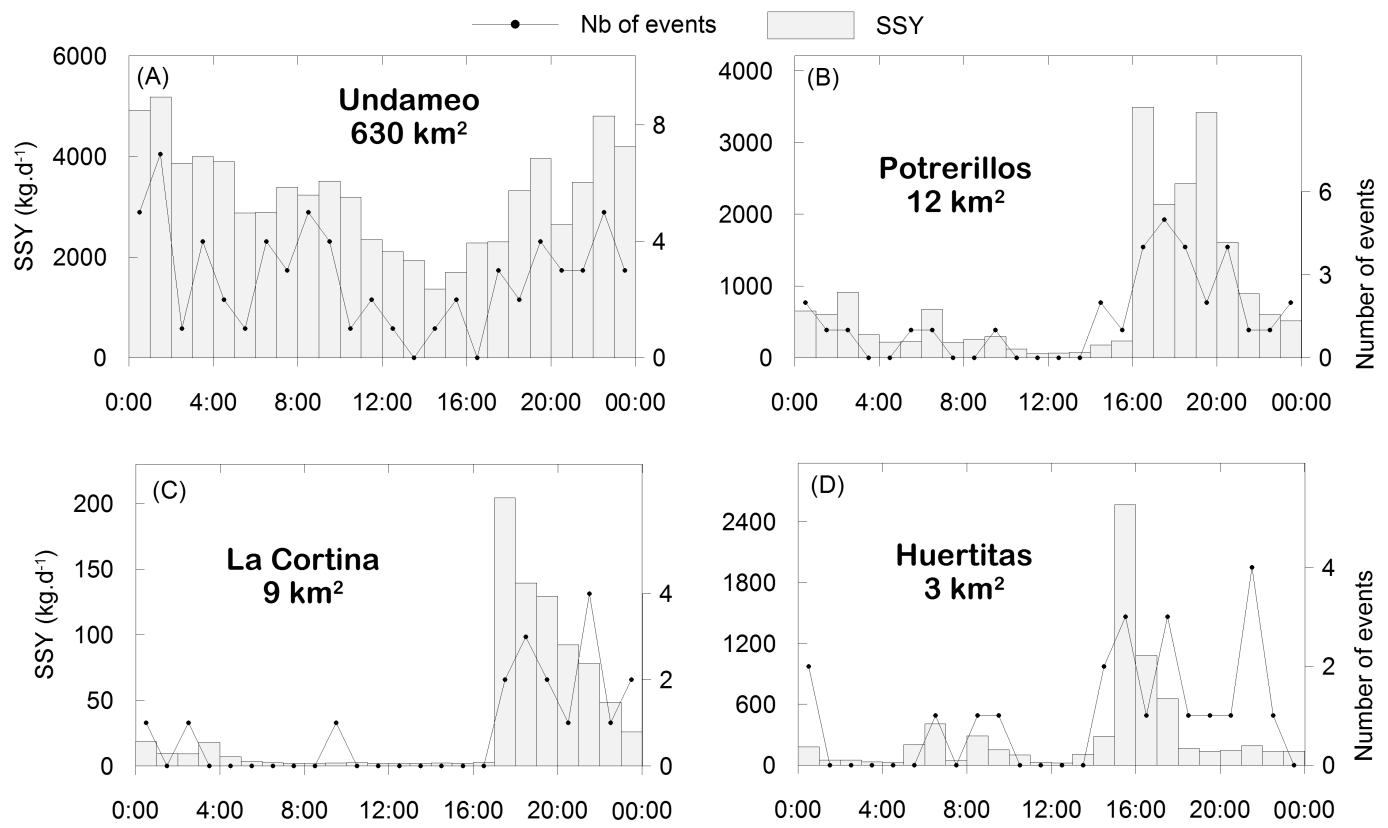

Fig. 5. Distribution of daily SSY in 2009 at the four stations. Black line plots correspond to the number of peak flow events per hour.

\subsection{Benefits of an adapted sampling time}

Errors in SSY estimates associated with a change in daily sampling time were assessed by simulating $\mathrm{S}_{0}$ to $\mathrm{S} 5_{23}$ scenarios. The results are presented in Fig. 6. At all sites, sampling time had a significant effect on flux estimate uncertainties. In Undameo (Fig. 6a), annual SSY was clearly underestimated or overestimated depending on the timing selected. For instance, daily sampling at night would lead to an overes- timation of ca. $50 \%$, whereas daily sampling in the afternoon would provide an underestimation of ca. $-50 \%$. In contrast, other time intervals would generate rather accurate yield estimates: the window ranging from early morning to midday maintained the error within the $\pm 20 \%$ range. This finding is of high importance in the perspective of implementing manual sampling strategies, as it could allow lowering the sampling frequency by $100 \%$ (i.e. shifting from S6 to an adapted S5). Furthermore, the daily sampling conducted by local 

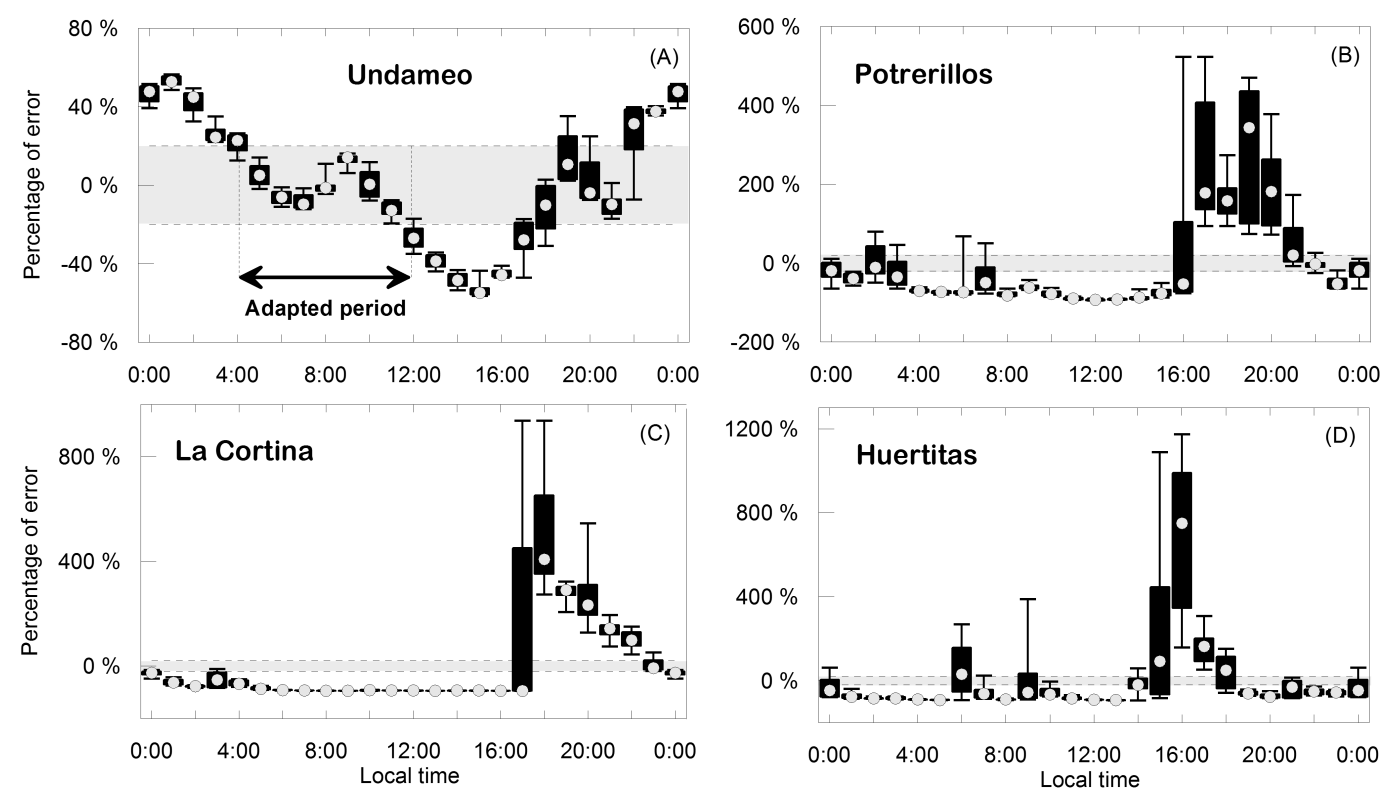

Fig. 6. Errors on SSY estimate related to $S 5_{0}$ to $S 5_{23}$ scenarios at each station. The $0 \%$ level represents $S S Y_{\text {ref. }}$ Grey circles correspond to median values, boxes correspond to lower and upper quartiles and whiskers correspond to maximum and minimum errors.

staff throughout 2009 around 07:00 p.m. led to a "real" SSY estimate of $56 \mathrm{Mg} \mathrm{km}^{-2}$. It corresponds to a positive bias of $25 \%$ in comparison to the reference flux. This result is in agreement with the slight overestimation that was provided by $\mathrm{S}_{19}$ scenario on yield estimates, as outlined in Fig. $6 \mathrm{a}$.

At the three subcatchments (Fig. 6b, c, d), the influence of SSC sub-daily variability was even more obvious, as previously expected by the analysis of Fig. 5. In La Cortina (Fig. 6c), daily sampling in the early morning to midafternoon would give a moderate to strong underestimation

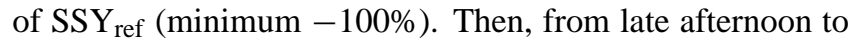
early night a high positive bias would be observed (maximum $+700 \%$ ) with remarkable differences between lower and upper quartiles. The return to "baseflow" was evidenced in the statistical series from early night. The behaviour observed in Huertitas (Fig. 6d) and Potrerillos (Fig. 6b) was similar to the one described in La Cortina, with the periods of flux overestimation slightly differing from one area to another: in Huertitas the "flooding" period occurred during the afternoon and in Potrerillos it was significantly more extended (i.e. from mid-afternoon to night). At the three sites, the choice of a sampling time during those periods would systematically provide very high uncertainties and imprecision of the estimates. In turn, this could lead to seriously biased interpretations of sediment transport within these small catchments.

\subsection{Towards an optimised community-based monitoring strategy}

We showed for the studied catchments that a high probability of systematic underestimation exists if the sampling fre- quency is not adapted. According to the classic randomlybased study of sampling frequency, a bi-daily sampling would be required at the outlet of the Cointzio basin (Undameo, $630 \mathrm{~km}^{2}$ ). However, this frequency could be lowered to a daily survey if a specific and regular sampling time window in the day (i.e. from early morning to midday) is considered, as outlined in Sect. 3.5.

In the three smaller catchments, the achievement of reliable SSY estimates proved to require very high sampling frequencies, i.e. hourly monitoring. We also showed that if considering a daily survey, even the use of a specific sampling time would lead to strong biases on annual SSY estimates (Fig. 6). This is particularly true if the time selected is concomitant with the period when high flows are most likely to occur. For instance, daily sampling in the afternoon in Huertitas could lead to a positive bias of up to $1200 \%$. This can be explained by the very short nature of events in these small areas ( 1 to $3 \mathrm{~h}$ ). Whatever the method considered (linear, nearest-neighbour, etc.), the interpolation of an instantaneous measurement taken during a flood to a daily flux inevitably leads to a substantial SSY overestimation. Trying to estimate annual yield by collecting samples during floods would thus be a counterproductive approach.

Our study provides a warning about the potential biases on annual flux estimates from a limited numbers of samples (even daily samples) in $1-10 \mathrm{~km}^{2}$ catchments dominated by convective rainfall. It therefore appears difficult to implement any community-based monitoring at such small scales. Nonetheless, rising stage samplers might be considered as a potential substitute for suspended sediment monitoring. They have been used in recent literature (e.g. Kostaschuk et 


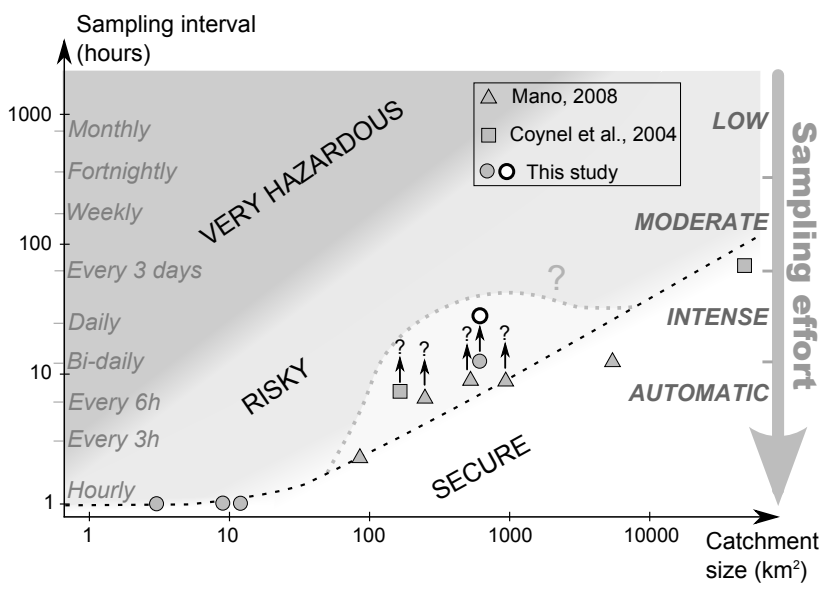

Fig. 7. Minimum sampling frequency requirements for the achievement of reliable SSY estimates. The white area indicates conditions allowing high-quality estimates (i.e. maximum errors within $\pm 20 \%$ ), the light-grey area corresponds to conditions leading to potentially risky estimates (i.e. 25 and 75 quartiles within $\pm 20 \%$ ), and the dark-grey area refers to conditions that can induce doubtful calculations. Circles correspond to data from this study, squares correspond to data from Coynel et al. (2004), and triangles to data from Mano (2008). The rounded dashed grey line in the centre of the figure refers to an elevation of the boundary between secure and risky estimates, which is likely to occur if the sub-daily cycle of sediment fluxes is considered. The shift from a grey to a white circle is an illustration of our results in Undameo (i.e. lowering of the sampling frequency from bi-daily to daily).

al., 2003; Francke et al., 2008), and could be implemented in small mountainous catchments where automated instrumentation is not feasible for monetary constraints. Yet, this sampling alternative requires further testing and validation.

We further enlarged the scope of our results by providing comparison with previous research on the topic. Our aim was to determine whether general trends were detectable in the minimum sampling frequencies required for SSY estimates of rivers draining mountainous areas. In the medium term, this approach should lead to the proposal of useful decisionmaking tools to the local stakeholders, for the implementation of river monitoring procedures in ungauged catchments.

Two important determinants of the accuracy and precision of SSY estimates are sampling frequency and catchment scale (Phillips et al., 1999). Figure 7 hence summarises the required sampling designs according to the catchment area for catchments dominated by convective rainfall. Values displayed in Fig. 7 correspond to data from this study as well as data from Coynel et al. (2004), obtained in the French Pyrenees (Garonne river basin), and from Mano (2008), obtained in various catchments in the French Alps. The three classes previously formulated as part of Fig. 4 (i.e. secure, potentially risky and hazardous estimates) were used again here. All data followed a common positive trend between sampling interval and catchment size (dashed black curve in Fig. 7). As already outlined, little data is available for $1-100 \mathrm{~km}^{2}$ catchments, but still, high frequency measurements appeared inevitable for these catchments. In contrast, values in the $100-1000 \mathrm{~km}^{2}$ range lie at the limit between automatic and manual strategies (we considered that manual sampling could be conducted from a bi-daily frequency for the most intense scenario). Sampling frequencies might be lowered within those catchments by accounting for the subdaily variability of sediment fluxes, as demonstrated by our results in the Cointzio basin (shifting from a grey to a white circle in Fig. 7). All those $100-1000 \mathrm{~km}^{2}$ values might therefore be substantially raised, as outlined in the figure (black arrows). In turn, this could allow reconsidering the potential of manual sampling strategies in various areas. Therefore, in small to medium-sized catchments dominated by convective rainfall the effort has to be concentrated on the assessment of sediment sub-daily variability in order to check if less intense sampling strategies could be implemented.

To further strengthen our results, similar surveys should be conducted over a larger number of years and in other upland catchments of the world undergoing different precipitation regimes. Our approach would then benefit from more reliable trends covering a wide range of hydrological situations that would not be skewed by any major event or meteorologically extreme year.

\section{Conclusions}

Small mountainous catchments face serious human and societal issues, especially in the rural areas of developing countries, where natural resources are under increasing human pressure. In this study, we intended to provide a better understanding of suspended sediment dynamics and variability within these areas. We studied the sediment flux records of four mountainous catchments $\left(3\right.$ to $630 \mathrm{~km}^{2}$ ) located in a rural region of central Mexico where rainfall is predominantly from convective storms occurring in the late afternoon through early night. The objective was to propose adapted strategies for the implementation of local river monitoring initiatives.

All catchments exhibited a high temporal variability in terms of both streamflow and sediment transport regime. This variability was observed at various time-scales: (i) river flow and suspended sediment flux were characterised by a pronounced seasonal cycle, and (ii) short-term dynamics (i.e. daily and sub-daily) were also very variable, with half of the annual SSY carried between $2 \mathrm{~h}$ and 4 days. Overall, the extent of temporal variations in sediment flux proved to be highly catchment size-dependent; smaller catchments having a higher variability in sediment response and a higher reactivity to storms than larger catchments.

The effect of sampling frequency on flux estimates was assessed. We showed that increasing the time interval between sampling was feasible by accounting for the sub-daily 
variability in suspended sediment flux. The choice of an appropriate sampling time during the day would indeed allow a reduction of the frequency of measurement at the mesoscale catchment $\left(630 \mathrm{~km}^{2}\right)$. This could be of useful interest from the perspective of the initiation of water surveys managed by local communities. In contrast, estimating annual yields at the three smaller catchments $\left(3-12 \mathrm{~km}^{2}\right)$ from daily data could lead to serious misinterpretation (i.e. up to $1000 \%$ error), and a high frequency sampling strategy is needed in those areas. This requirement can not reasonably be met by manually collected individual samples; however, rising stage sampling can potentially be a valuable alternative to automated instrumentation, but this still has to be fully explored.

Additionally, our results outline the importance of characterising the sub-daily variability of sediment fluxes, for conveniently assessing the reliability of historical records based on discrete sampling. This methodology will serve as a guideline to calculate annual sediment yields from the daily SSC values measured by the CONAGUA between 1939-2002.

Overall, it is of high importance to promote the development of community-based monitoring of catchments in Mexico and elsewhere, and to strengthen the linkages between local groups, management authorities and researchers. The implementation of such programs would allow collection of comprehensive databases on soil loss and land degradation, but also on the chemical and biological quality of rivers. Accordingly, further investigations within small mountainous catchments are required to gain better insights into sediment and nutrient flux variability.

Acknowledgements. This work was funded by the French National Research Agency (ANR) through the STREAMS project, coordinated by M. Esteves, and by the European DESIRE project, locally coordinated by $\mathrm{C}$. Prat. The authors wish to thank all the personal involved in field and laboratory works. We are also grateful to G. Bocco, O. Evrard and T. Grangeon for their support and helpful comments. Finally, the CIGA and the CIEco (UNAM-campus Morelia) are kindly acknowledged.

Edited by: I. Tromp-van Meerveld

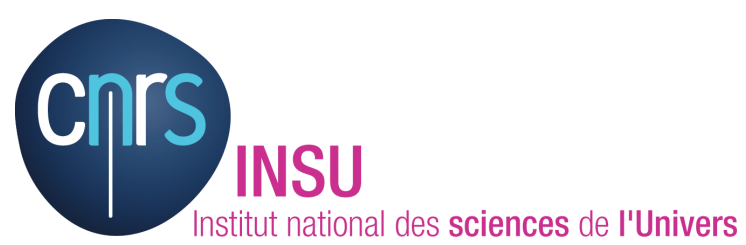

The publication of this article is financed by CNRS-INSU.

\section{References}

Alcocer, J. and Bernal-Brooks, F. W.: Limnology in Mexico, Hydrobiologia, 644, 15-68, 2010.

Aranda, E., Oral, R., Flores, A., Ramos, M., Vidriales, G., and Manson, R.: Monitoreo comunitario del agua, Asociación de Vecinos del Pixquiac - Zoncuantla, A.C., Global Water Watch-Veracruz, Instituto de Ecología, Xalapa, Mexico, Poster available at: http: //www.globalwaterwatch.org/Mexico/Docs/Cartel08.pdf, 2008.

Bocco, G., Velázquez, A., and Siebe, C.: Using geomorphologic mapping to strengthen natural resource management in developing countries, the case of rural indigenous communities in $\mathrm{Mi}$ choacán, Mexico, Catena, 60, 239-253, 2005.

Carlón-Allende, T., Mendoza, M. E., López-Granados, E. M., and Morales-Manilla, L. M.: Hydrogeographical regionalization: an approach for evaluating the effects of land cover change in watersheds, a case study in the Cuitzeo lake watershed, Central Mexico, Water Resour. Manag., 23, 2587-2603, 2009.

Coynel, A., Schafer, J., Hurtrez, J. E., Dumas, J., Etcheber, H., and Blanc, G.: Sampling frequency and accuracy of SPM flux estimates in two contrasted drainage basins, Sci. Total Environ., 330, 233-247, 2004.

de Boer, D. H., Froehlich, W., Mizuyama, T., and Pietroniro, A.: Preface, in: Erosion prediction in ungauged basins (PUBs): integrating methods and techniques, de Boer, D. H., Froehlich, W., Mizuyama, T., and Pietroniro, A. (Eds.), Proceedings of the Sapporo Symposium, Dec 2003, IAHS Publication, 279, V-VII, 2003.

de Vries, A. and Klavers, H. C.: Riverine fluxes of pollutants: monitoring strategy first, calculation methods second, Eur. Water Pollut. Control, 4, 12-17, 1994.

Deutsch, W. G. and Orprecio, J. L.: Water quality changes in the Manupali River watershed: evidence from a community-based water monitoring project, in: Land use change in tropical watersheds, edited by: Coxhead, I. and Shiveli, G. E., CAB International Publishing, 37-57, 2005.

Dietrich, W. E. and Dunne, T.: Sediment budget for a small catchment in mountainous terrain, Zeits. Geomorph., 29, 191-206, 1978.

Duvert, C., Gratiot, N., Evrard, O., Navratil, O., Némery, J., Prat, C., and Esteves, M.: Drivers of erosion and suspended sediment transport in three headwater catchments of the Mexican Central Highlands, Geomorphology, 123, 243-256, 2010.

Evrard, O., Némery, J., Gratiot, N., Duvert, C., Ayrault, S., Lefèvre, I., Poulenard, J., Prat, C., Bonté, P., and Esteves, M.: Sediment dynamics during the rainy season in tropical highland catchments of central Mexico using fallout radionuclides, Geomorphology, 124, 42-54, 2010.

Fernandez-Gimenez, M. E., Ballard, H. L., and Sturtevant, V. E.: Adaptive management and social learning in collaborative and community-based monitoring: a study of five community-based forestry organizations in the western USA, available at: http/ /www.ecologyandsociety.org/vol13/iss2/art4, Ecol. Soc., 13(4), 2008.

Food and Agriculture Organization of the United Nations (FAO): World Reference Base for Soil Resources 2006, a framework for international classification, correlation and communication, FAO, World Soil Resources Report, 103, Rome, Italy, 2006.

Francke, T., López-Tarazón, J. A., Vericat, D., Bronstert, A., Batalla, R. J.: Flood-based analysis of high-magnitude sedi- 
ment transport using a non-parametric method, Earth Surf. Proc. Land., 33, 2064-2077, 2008.

Gippel, C. J.: Potential of turbidity monitoring for measuring the transport of suspended-solids in streams, Hydrol. Process., 9, 8397, 1995.

Gratiot, N., Duvert, C., Collet, L., Vinson, D., Némery, J., and Sáenz-Romero, C.: Increase in surface runoff in the central mountains of Mexico: lessons from the past and predictive scenario for the next century, Hydrol. Earth Syst. Sci., 14, 291-300, doi:10.5194/hess-14-291-2010, 2010.

Horowitz, A. J.: An evaluation of sediment rating curves for estimating suspended sediment concentrations for subsequent flux calculations, Hydrol. Process., 17, 3387-3409, 2003.

Horowitz, A. J.: Determining annual suspended sediment and sediment-associated trace element and nutrient fluxes, Sci. Total Environ., 400, 315-343, 2008.

Kostaschuk, R. A., Terry, J., and Raj, R.: Suspended sediment transport during tropical-cyclone floods in Fiji, Hydrol. Process., 17, 1149-1164, 2003.

Lewis, J.: Turbidity-controlled suspended sediment sampling for runoff-event load estimation, Water Resour. Res., 32, 2299 2310, 1996.

Lewis, J. and Eads, R.: Implementation guide for turbidity threshold sampling: principles, procedures, and analysis, General Technical Report PSW-GTR-212, Albany, CA, USDA Forest Service, Pacific Southwest Research Station, 86 pp., 2008.

Mano, V.: Processus fondamentaux conditionnant les apports de sédiments fins dans les retenues - Optimisation des méthodes de mesure et modélisation statistique, Ph.D. thesis, University of Grenoble, France, 312 pp., 2008.

Mano, V., Némery, J., Belleudy, P., and Poirel, A.: Suspended particle matter dynamics in four alpine watersheds (France): influence of climatic regime and optimization of flux calculation, Hydrol. Process., 23, 777-792, 2009.

Meybeck, M., Laroche, L., Durr, H. H., and Syvitski, J. P. M.: Global variability of daily total suspended solids and their fluxes in rivers, Global Planet. Change, 39, 65-93, 2003.

Milliman, J. D. and Syvitski, J. P. M.: Geomorphic/tectonic control of sediment discharge to the ocean: the importance of small mountainous rivers, J. Geol., 100, 525-544, 1992.

Moatar, F., Person, G., Meybeck, M., Coynel, A., Etcheber, H., and Crouzet, P.: The influence of contrasting suspended particulate matter transport regimes on the bias and precision of flux estimates, Sci. Total Environ., 370, 515-531, 2006.

Moatar, F., Birgand, F., Meybeck, M., Faucheux, C., and Raymond, S.: Uncertainties on river water quality metrics assessment (nutrients, concentration quantiles and fluxes) based on discrete surveys, Houille Blanche, 3, 68-76, 2009.

Morehead, M. D, Syvitski, J. P. M., Hutton, E., and Peckham, S.: Modelling the temporal variability in the flux of sediment from ungauged river basins, Global Planet. Change, 39, 95-110, 2003.

Navratil, O., Esteves, M., Legout, C., Gratiot, N., Némery, J., Willmore, S., and Grangeon, T.: Global uncertainty analysis of suspended sediment monitoring using turbidimeter in a small mountainous river catchment, J. Hydrol., 398, 246-259, 2011.

Némery, J., Mano, V., Navratil, O., Gratiot, N., Duvert, C., Legout, C. Belleudy, P., Poirel, A., and Esteves, M.: Feedback on the use of turbidity in mountainous rivers, Techniques Sciences Méthodes, 1-2, Jan-Feb 2010, Association Scientifique et Tech- nique pour l'Eau et l'Environnement, Paris, France, 61-68, 2010.

Ongley, E., Ralston, J., and Thomas, R.: Sediment and nutrient loadings to lake Ontario: methodological arguments, Can. J. Earth Sci., 14, 1555-1565, 1977.

Ortiz-Ávila, T.: Estrategia interinstitucional para el quehacer ambiental municipal en Michoacán: experiencias y propuestas de la Unidad de Vinculación del CIEco, Conference of the Centro de Investigaciones en Ecosistemas, UNAM-Morelia, Mexico, April 2009.

Paré, L., Fuentes, T., García, I., Gerez, P., Muñiz-Castro, M., and Vidriales, G.: Gestión de la cuenca del Río Pixquiac y su interacción con la zona conurbada de Xalapa: esfuerzos desde la sociedad civil, in: La gestión de los recursos hídricos: realidades y perspectivas, Soares, D., Vargas, S., and Nuño, M. R. (Eds.), Instituto Mexicano de Tecnología del Agua, Jiutepec, Mexico, 228-256, 2008.

Phillips, J. M., Webb, B. W., Walling, D. E., and Leeks, G. J. L.: Estimating the suspended sediment loads of rivers in the LOIS study area using infrequent samples, Hydrol. Process., 13, 10351050, 1999.

Savan, B., Morgan, A. J., and Gore, C.: Volunteer environmental monitoring and the role of the universities: the case of Citizens' Environment Watch, Environ. Manage., 31, 561-568, 2003.

Sharpe, A. and Conrad, C.: Community-based ecological monitoring in Nova Scotia: challenges and opportunities, Environ. Monit. Assess., 13, 305-409, 2006.

Sidle, R. C., Tsuboyama, Y., Noguchi, S., Hosoda, I., Fujieda, M., and Shimizu, T.: Stormflow generation in steep forested headwaters: a linked hydrogeomorphic paradigm, Hydrol. Process., 14, 369-385, 2000.

Syvitski, J. P. M. and Morehead, M. D.: Estimating river-sediment discharge to the ocean: application to the Eel margin, northern California, Mar. Geol., 154, 13-28, 1999.

Velázquez, A., Fregoso, A., Bocco, G., and Cortez, G.: Strengthening long term forest management, the use of a landscape approach in Mexican forest indigenous communities, Interciencia, 28, 632-638, 2003.

Walling, D. E. and Webb, B. W.: The reliability of suspended sediment load data: erosion and sediment transport measurement, Proceedings of the Florence Symposium, June 1981, IAHS Publication, 133, 177-194, 1981.

Walling, D. E. and Webb, B. W.: Erosion and sediment yield, a global overview, in: Erosion and sediment yield: global and regional perspectives, edited by: Walling, D. E. and Webb, B. W., Proceedings of the Exeter Symposium, Jul 1996, IAHS Publication, 236, 3-19, 1996.

Walling, D. E., Collins, A. L., Sichingabula, H. M., and Leeks, G. J. L.: Use of reconnaissance measurements to establish catchment sediment budgets: a Zambian example, in: Erosion prediction in ungauged basins (PUBs): integrating methods and techniques, edited by: de Boer, D. H., Froehlich, W., Mizuyama, T., and Pietroniro, A., Proceedings of the Sapporo Symposium, Dec 2003, IAHS Publication, 279, 3-12, 2003.

Whitelaw, G., Vaughan, H., Craig, B., and Atkinson, D.: Establishing the Canadian community monitoring network, Environ. Monit. Assess., 88, 409-418, 2003. 